\title{
The Role of Financial Constraints in Business Environment; Evi- dence from Business Group Affiliated and Non-Affiliated Firms in Pakistan
}

\author{
Saba Aslam*1 \& Dr. Muhammad Khalid Sohail ${ }^{2}$ \\ ${ }^{1}$ COMSATS University, Islamabad, Pakistan \\ 2 Bahria University, Islamabad, Pakistan
}

\begin{abstract}
The main purpose of this study is to investigate the relationship between Cash Flows, Growth Opportunities, Firm Size, Firm Age, Firm Performance, Investment, Financial constraints and Leverage between the B.G AFs and NAFs of Pakistan. Current study consists of the balanced panel data containing 86 B.G AFs vs. 90 NAFs of the Pakistan. This study covers the yearly data period from 2007 to 2017. The findings showed that the cash flows are positively correlated with the return on assets, investments, financial constraints, while leverage is negatively correlated with the financial constraints. The positive correlation between cash flows and return on asset is higher for the B.G AFs, which means the B.G AFs are more profitable than the NAFs. The correlation of cash flows with the investment and financial constraints is positive but lower for the B.G AFs, showing that AFs investment is less sensitive and less financially constrained than NAFs. The inverse correlation between leverage and financial constraints shows that the B.G AFs have easy access to the financial sources. The positive and higher correlation of growth opportunities with cash flows and return on assets shows that the AFs growth is higher than NAFs.
\end{abstract}

Key words: B.G AFs and NAFs, KSE-100, Financing Constraints

\section{Introduction}

The economic legal system is not effective because this system cannot shield investor's rights and creates difficulties for companies if they want to raise the external financing. So, the firms are structured into B.Gs to enjoy the benefits of operational and financial inter-linkages. According to previous study on BGs, risk is divided among member firms of the B.Gs and firms to overcome constraints by raising the external capital (Gopalan et al., 2007). B.G AFs can be defined as, if the group firms owned at-least $20 \%$ stocks of the other firms, and then the firms whose stocks have been owned are B.G AFs (Claessens et al., 2006). B.G AFs use intra-group loans in time of financial needs (Gopalan et al., 2007). Constraints may be internal (lack of knowledge or poor cash flow) or external (interest rates) that may resist investment purpose.

${ }^{*}$ Corresponding author.

Email: finance12info@gmail.com 
Businesses can easily control internal constraints while, it is difficult for firms to control external constraints.

B.G AFs accounting and stock market performance is higher than NAFs and the results showed the positive effect of firm performance on B.G affiliation (Ahmad et al., 2018). The study showed that the B.G AFs face less financing constraints because they have lower investment cash flow sensitivities (Makina and Wale, 2016). The findings suggested that there is a strong positive effect of group affiliation on firms performance than NAFs (Gedefaw Birhanu and Wezel, 2020). The findings suggested that the B.G AFs can easily access the external financing (Jung et al., 2019). The results indicated that the B.G AFs can access in the better way to the leverage opportunities and performed better than NAFs (Purkayastha, 2018). The findings showed the positive relationship between investment, leverage and profitability of B.G AFs (Yana, 2020).

The existing literature could not clearly check the correlation between financing constraints, Investment cash flows sensitivities, firm size, firm age, firm performance, cash flows of AFs and non AFs. Most studies have checked the impact of external factors on Investment. So, our study attempts to check the correlation among different variables (cash flows, growth opportunities, firm size and firm age, firm profitability, investment, leverage and financial constraints) of B.G AFs and NAFs. Our study is significant because it covers the Pakistani B.G AFs and NAFs; however, the majority research has been conducted on other countries not including Pakistan. Our study also compared the results of AFs with NAFs. The problem statement of our study is; What would be the performance of firms when they AFs with a B.Gs vs. when they do not AFs with any business group?

Our study creates new knowledge of relationships between variables and investment as well as profitability of AFs (NAFs). The study covers Pakistani B.G AFs and NAFs. This research is significant for investors, government, managers, policymakers and financial institutions. It provides pro-active suggestions that there is higher probability, which NAFs that will face hurdles in obtaining loans from external markets due to weak financial reputation.

\section{Literature Review}

The bank B.G AFs are large with a low debt level, because they have a direct and access to the capital market (Malik, 2018). There is a positive correlation between B.G affiliation and ROA that has been empirically supported (Gedefaw Birhanu and Wezel, 2020). B.G AFs have more tendency to finance their investments rather than NAFs (Jindal and Seth, NA). BG affiliation positively influences the ROA (Castaldi et al., 2019). B.G AFs have the highest ROA and Tobin's Q than NAFs (Ahmad et al., 2018).

Member firms of a B.G provide a shield to the B.G AFs and protect them from the external risks. So, the B.G AFs are more profitable and less risky (Lin et al., 2019). FS showed a significant negative effect on ROA, representing that small firms outperform than large firms (Sanan et al., 2019). The result showed that CF negatively affects the investment of B.G AFs, while the cash flow positively affects the investment of NAFs. However, the results are insignificant in both the cases. But the interaction coefficients are negatively significant for B.G AFs only (Mehmood and Farid Hasnu, 2019). The results showed that, B.G AFs significantly affects the firm performance. Additionally, the size and the sales growth positively affected the firms performance (Ahmad et al., 2018).

B.G AF's risk-taking power is less than non-group firms (Subramaniam, 2019). B.G AFs have low investment CF sensitivity (Yeh and Lin, 2020). There exists the inverse correlation between 
leverage and the performance of B.G AFs (Carney et al., 2011). The study revealed that group affiliation has a direct correlation with corporate (Gupta and Mahakud, 2018). Study revealed negative association between leverage and investment (Ghatak and Kali, 2001).

The results showed that the B.G AFs outperformed NAFs (Ahmad et al., 2018). The findings revealed that the B.G AFs are less financially constrained because these firms have lower investment CF sensitivities (Makina and Wale, 2016). The findings suggested that the group affiliation has a strong direct impact on firm's performance than NAFs (Gedefaw Birhanu and Wezel, 2020). The findings revealed that NAFs are more financially constrained than B.G AFs (Yeh and Lin, 2020). The results of this study showed that the diversified B.G AFs are more profitable and bear less financial constraints (Ellouze and Mnasri, 2020).

The findings suggested that the B.G AFs have easy access to external financing (Jung et al., 2019). The results indicated that the B.G AFs can easily achieve the leverage opportunities and performed better than NAFs (Purkayastha, 2018). The findings suggested a direct association among investment, leverage and profitability of B.G AFs. It shows that the internal capital markets of B.Gs are the main source to decrease the financial constraints of B.G AFs (Yana, 2020). Performance is positively correlated with the group affiliation (Poczter, 2018). The results showed that the NAFs investment decisions are highly sensitive to the cash flow (Kumar and Ranjani, 2018).

A study revealed that there is a significantly direct association between cash flow coefficient and AFs (Lensink et al., 2003). The outcomes showed a direct and significant relationship between cash flows and investments of Group AFs and NAFs (George et al., 2011). They found a direct relationship between investment and growth opportunity of B.G AFs (Shin and Park, 1999). AFs investment is positively correlated with the growth opportunity (Buchuk et al., 2014). The findings showed an opposite correlation between net group financing and performance of group firms. Similarly, group size and group diversification inversely affected the firm's profitability (Kirch and Kabbach-Castro, 2016). There is a direct relationship between firms investment and cash flows of B.G AFs (He et al., 2013). Group affiliation is positively correlated with the firm's value and the firm's performance. Meanwhile, the firm size and the growth opportunity is inversely correlated with the leverage (Ghosh, 2010). Their research showed that the financially constrained organizations can easily get external funds through financial liberalization (Ghosh, 2010). Results showed that the small firms face lower investment sensitivities (Gorodnichenko et al., 2009). Study showed that the group affiliation positively affects the firm's profitability (Ghosh, 2010). In our opinion, the B.G AFs perform better than NAFs. B.G AFs have higher opportunities to grow; they face less financial constraints and fulfill their financial needs through the financial institutions. NAFs are less leveraged due to their weak financial reputation, as the investment in NAFs may be riskier.

\subsection{Theoretical Framework}

If the firms are financially constrained, they face difficulties obtaining financial assistance from the external sources. Then the companies rely on the internal funds to fulfill their monetary desires. This reflects the pecking order theory that states, if the firm needs financing then it should use internal funding first and then move towards the external funding (Myers and Majluf, 1984). This study suggests that if the impact of cash flow is positive on the investment, then it means that the firm is financially constrained (Saeed and Athreye, 2014). Financially constrained firms face difficulty getting external financial sources. However, the financial need is still there and companies need funds to fulfill their financial needs. It reflects the pecking 
order theory of capital structure. Pecking order theory was first suggested by Donaldson et al. (1961). Afterward, it was modified by Myers and Majluf (1984) that made it popular. Hence according to this theory, our study suggested that financially constrained firms face difficulties obtaining financial assistance from the outside financial institutions. So, the companies rely on their internal funds to fulfill their monetary desires. Modigliani and Miller (1958) proposed the Trade-off theory; trade off theory states that, if the firm needs funds then it relies on debt over equity in order to avail the tax-shield benefit. This theory guides the companies and suggests selecting debt finance and equity finance to maintain a balance between the costs and benefits (Modigliani and Miller, 1958).

The firms avail debt to meet their financial needs then they pay interest over it. Afterward, firms pay taxes over it. Because interest is tax exempted hence, the firms can enjoy tax shield benefit (Cotei and Farhat, 2009). In the case of B.G AFs, if the relationship between the coefficient of interaction term (2 CFit x BGit) of B.G AFs and the investment or the firm performance is negative, then it shows that the firm is relying on external funds because the firm is financially non-constrained and satisfying its financial needs for funds. This idea is the reflection of trade off theory (Saeed and Athreye, 2014).

\subsection{Hypotheses Development}

\subsubsection{Firm Performance}

B.Gs help the AFs to defeat deficiencies in external market and increase their growth opportunities (Lamin, 2013; Purkayastha, 2018). B.Gs help the AFs to perform and survive effectively (Belenzon et al., 2013). Similarly, B.G affiliation assists member firms if the facing diversities in the external surroundings (Gubbi et al., 2015). There is a positive impact of B.G affiliation on the financial performance (Castaldi et al., 2019). Based on the above arguments, we expect that the B.G AFs are more profitable than NAFs so, we propose the following hypothesis:

H1: Higher Cash flows increases the performance of AF's as compared to NAFs

\subsubsection{Investment}

Investment means how much the firms are sensitive to their investment. Quite a few studies checked the investment-cash flow association for B.Gs of the different countries. The investment of NAFs are more risky than B.G AFs (Subramaniam, 2019). Japanese B.G firms showed less investment CF sensitivities. George et al. (2011) found that the non group firms in the Japan and Korea showed the positive investment CF sensitivity. Kato et al. (2002) showed the minor sensitivity related to the Japanese B.G AFs. Lensink et al. (2003) found that the effect of CF on investment is less than that of NAFs. So for the B.G AFs, investment CF's sensitivity is less than that of NAFs. The above arguments logically lead to our expectation that the B.G affiliation reduces the sensitivity of investment spending to the cash flows. Hence, our second hypothesis is as follows;

H2: Lower Investment of AFs decreases the Cash Flows Sensitivity of AF's than NAFs

\subsubsection{Financial Constraints}

Financial constraint means the firms face difficulties obtaining loan and access financial market. NAFs bear more financial constraints than B.G AFs (Shin and Park, 1999), and can reach to the external capital markets. The B.G AFs can easily reach to the financial markets (Almeida et al., 2015; Carney et al., 2011; Chang and Hong, 2000; Khanna and Palepu, 2000). Additionally, 
member firms lend money to the B.G AFs at a rate lower than that of the external financial market (Gopalan et al., 2007; Liebeskind, 2000). Based on the above arguments related to financial constraints, we expect that B.G AFs are less financially constrained than NAFs. Therefore, our third hypothesis is;

H3: Lower Financial constraints increase availability of funds for AF's than NAFs

\subsubsection{Leverage}

Leverage means the firms can easily obtain loans in the times of financial need. The B.G AFs are having higher leverage relatively NAFs (Mehmood and Farid Hasnu, 2019). B.G AFs have easy access to the external financial markets (Aggarwal et al., 2019). The existence of intragroup debt confirms the B.G member firms to facilitate the financial access. Ghatak and Kali (2001) found that the B.Gs try to find more borrowings. The B.G AFs are more leveraged as they can easily reach to the loan (Carney et al., 2011). As a result we expect that B.G AFs are more leveraged than NAFs and have easy access to the financial sources and capital markets. Therefore, they can enjoy the tax shield benefit. Thus, we proposed our last hypothesis that is;

H4: Higher Leverage increases access to the cheap source of financing for AFs than NAF's.

\section{Methodology and Data Collection}

\subsection{Sample and Procedure}

Our sample consists of 176 companies including 86 AFs and 90 NAF Pakistani firms covering 11-year data for the period of 2007 to 2017. Frequency of our data is yearly. Moreover, the source of our data is financial statements of the B.G AFs and NAFs. We categorize our sample in the following two parts; first is the B.G AFs while, the second is NAFs. A Multiple Linear Regression model has been adopted to observe the effects of cash flows, growth opportunities, firm size, firm age and interaction term on the firm performance, investment, leverage and financial constraints.

\subsection{Multiple Linear Regression Model}

Previous studies suggested that since the B.G AFs help in reducing their financial constraints, these firms face lower investment CF sensitivity. Conversely, NAFs are high risky and face more changing threats thats why study is more emphasized on AFs and NAFs of Pakistan. The study of Mehmood and Farid Hasnu (2019) suggested that if the credit is a main problem for the entrepreneur, then the firm is financially constrained and vice versa. Their results confirmed that the firms having a positive sensitivity of cash holding and cash flows are more likely to be the financially constrained. Furthermore, the results showed that the B.G AFs in Pakistan are less financially constrained as compared to the NAFs.

According to Gohar (2013), in Pakistan the NAFs are less liquid and leveraged than AFs. The results of Malik (2018) showed that the group affiliation is positively correlated with the firm's leverage. Mukherjee and Chanda (2021) concluded that the high leverage is a solution of financing constraints and helps the firms to access the external financial resources. The study of Makina and Wale (2016) showed that the coefficients of the investment and CF are negative. As a result they found that, the B.G AFs are lowered financially constrained and thus, have lower investment CF sensitivities. 
The outcomes of Lensink et al. (2003) confirmed the lower correlation coefficient for AFs than for NAFs. It means the B.G AFs are less sensitive of its investments. Investment is a negatively related to the cash flow of B.G AFs (Moyen, 2004). There are four regression models in our research. Regression equations showing the effect of independent variables on dependent variable are as follows, and Table 3.1 is showing the variable's measurement for the Multiple Linear Regression.

$$
\begin{array}{r}
\text { PerformanceofBG } \mathbf{B G}_{\mathbf{i t}}=\alpha+\beta_{1}\left(C F_{i t}\right)+\beta_{2}\left(C F_{i t} * B . G_{i t}\right)+\beta_{3}\left(B . G_{i t}\right)+\beta_{4}\left(G O_{i t}\right)+\beta_{5} \\
\left(F S_{i t}\right)+\beta_{6}\left(F A_{i t}\right)+\varepsilon_{i t}
\end{array}
$$

$$
\begin{array}{r}
\text { InvestmentofBG } \mathbf{G}_{\mathbf{i t}}=\alpha+\beta_{1}\left(C F_{i t}\right)+\beta_{2}\left(C F_{i t} * B . G_{i t}\right)+\beta_{3}\left(B . G_{i t}\right)+\beta_{4}\left(G O_{i t}\right)+\beta_{5} \\
\left(F S_{i t}\right)+\beta_{6}\left(F A_{i t}\right)+\varepsilon_{i t}
\end{array}
$$

$$
\begin{aligned}
& \text { F.CofBG }_{\text {it }}=\alpha+\beta_{1}\left(C F_{i t}\right)+\beta_{2}\left(C F_{i t} * B . G_{i t}\right)+\beta_{3}\left(B . G_{i t}\right)+\beta_{4}\left(G O_{i t}\right)+\beta_{5}\left(F S_{i t}\right)+\beta_{6} \\
& \left(F A_{i t}\right)+\varepsilon_{i t}
\end{aligned}
$$

$$
\begin{array}{r}
\text { LeverageofBG } \mathbf{B G}_{\mathbf{i t}}=\alpha+\beta_{1}\left(C F_{i t}\right)+\beta_{2}\left(C F_{i t} * B . G_{i t}\right)+\beta_{3}\left(B . G_{i t}\right)+\beta_{4}\left(G O_{i t}\right)+\beta_{5}\left(F S_{i t}\right) \\
+\beta_{6}\left(F A_{i t}\right)+\varepsilon_{i t}
\end{array}
$$

\subsection{Variables and Proxies}

Table 3.1 shows the proxies of all variables considered in this research. Leverage, Investment, Financing constraints and Firm performance are dependent variables. While Cash flows, growth opportunity, dummy variable and interaction term are independent variables. However, firm size and firm age are control variables.

\subsubsection{Dependent Variables}

\subsubsection{Leverage (LEV)}

Leverage is measure by the total debt divided by the total assets. Leverage tells us that how much a firm has access to the debt and finance. Indeed, the firm is said to be leveraged if it has a easy access to the finances. The research conducted by Carney et al. (2011) showed that the B.G AFs are more leveraged than NAFs and have easy access to the financial sources than NAFs. Further their outcomes showed that, B.G affiliates use debt (leverage) financing in a better way.

\subsubsection{Investment (INV)}

It is investment in the fixed assets. It is equal to purchase of plant, property or any other fixed assets. Investment is measured by the total assets of current year divided by the total assets of previous year. Gopalan et al. (2007) also used this ratio to measure the investment. It tells us that how much the investment of a firm is sensitive and fluctuates due to the external 
factors. Identically, quite a few studies analyzed the investment-cash flow relationship for the B.Gs of different countries. The investment of B.G AFs is less risky than NAFs (Subramaniam, 2019).

Japanese B.G firms showed less investment cash flow sensitivities. NAFs in the Japan and Korea showed direct correlation of investments with cash flows (George et al., 2011). Besides this, (Kato et al., 2002) found a minor sensitivity related to the Japanese B.G AFs.

\subsubsection{Financing Constraints (F.C)}

We measured financing constraints by the investment cash flow sensitivity and the formula of investment CF sensitivity is the current year cash flows divided by the previous year investment. The study of Mehmood and Farid Hasnu (2019) described that firms are financially constrained if the firms are highly sensitive to the cash flows. Similarly, Bhaduri (2005) found that the B.G AFs do not face financial constraints. On the other hand, Lensink et al. (2003) have investigated that the B.G affiliation lowers the sensitivity of investment spending to the cash flow. As a result they showed that, higher cash flows coefficient for standalone companies represents that the firm is financially constrained. The study of Ayyagari (NA) revealed the negative relationship between the financial constraints and the firm growth because relaxing financing constraints results in promoting firm's growth.

\subsubsection{Firm Performance (ROA)}

Firm performance is measured by the Return on Assets (ROA) that is equals to the Earnings Before Interest and Taxes divided by the Total Assets. Ahmad et al. (2018) adopted the same procedure to measure the firm's performance. B.Gs facilitate the AFs to overcome the external market deficiencies and increase their GO (Lamin, 2013; Purkayastha, 2018). Additionally, the B.Gs facilitate the AFs to compete effectively and survive (Belenzon et al., 2013; Estrin et al., 2009). Since, B.G affiliation facilitates the member firms if the firms face changing in the external environment (Gubbi et al., 2015). There is a positive effect of B.G affiliation on the ROA (Castaldi et al., 2019).

\subsubsection{Independent Variables}

\subsubsection{Cash Flows (CF)}

Cash flows can be calculated as Earnings Before Interest and Taxes (EBIT), Depreciation and Amortization. Mehmood and Farid Hasnu (2019) have investigated that firm's investment is very CF-sensitive. Therefore, cash flow is measured as (EBIT+Depreciation)/ Total Assets. By following the methodology adopted by Lensink et al. (2003), we use cash flows as a proxy for internal funds.

\subsubsection{Growth Opportunity (GO)}

Growth opportunity is measured by the natural log of current year's sales divided by the previous year's sales. Bhaduri (2005) concluded that the financially constrained firms face limited growth opportunities. Results of Ayyagari (NA) showed that 1 unit increase in the financial constraints leads to $8-10 \%$ reduction in the firm's growth. 


\subsubsection{Dummy Variable}

The value of dummy variable is 1 if the firms are AFs with a B.G and 0 otherwise. We can get Interaction term by multiplying the cash flows with the dummy variable. Ayyagari (NA) suggested that the B.G AFs outperform than NAFs. Similarly, Khanna and Palepu (2000) found that the group affiliation helps the firms to reduce financial constraints.

\subsubsection{Interaction Term}

We get an Interaction term by multiplying the cash flows with dummy variable (CF X Business Group). The study of Saeed and Athreye (2014) found that if the relationship between coefficient of interaction term (2 CFit x B.Git) of B.G AFs and investment and firm's performance is negative. It means that the firm is relying on external funds because firm is not financially constrained and satisfying its financial needs for funds. This idea is the reflection of trade off theory. Furthermore, Mehmood and Farid Hasnu (2019) have found that the coefficient of cash flows interacting with the B.G dummy is negative but statistically significant.

\subsubsection{Control Variables}

\subsubsection{Firm Size (FS)}

Firm size is calculated by taking the log of total assets. Firm size has widely been studies in the previous studies. Mehmood and Farid Hasnu (2019) suggested that the FS increases as the firm grows older and is closely related to the firm's profitability. Generally, it is expected that firms large in size have more access to the internal finance as compared to smaller firms.

\subsubsection{Firm Age (FA)}

Firm's age is the number of years since the firm is incorporated. Current year minus incorporation year is the formula to calculated firm's age. Identically, Mehmood and Farid Hasnu (2019) found that the older firms are more profitable as compared to younger firms. Similarly, VLACHVEI and NOTTA (2008) examined Greece firms and found that the coefficient of age is positive and significant. Additionally, Loderer and Waelchli (2010) studied the US COMPUSTAT Industry Segment between 1978 and 2004 to investigated how age affects a firms financial performance. They have found that age progressively impairs performance.

\section{Results}

Data is categorized into two parts. Fist part contains data of Pakistani B.G AFs that are 86 in number, while second part contains data of NAFs that are 90 in number. We compared the summary statistics of AFs and NAFs. Afterward, we checked the correlation and multicollinearity among different variables. Hausman test has been applied to check that either fixed effect model is appropriate or random effect model. Hausman test showed the probability value of 0 each time, hence we used fixed effect model. After that, according to the Hausman test, the Multiple Linear Regression analyses have been made by using fixed effect model to examine the relationship between Independent and Dependent variables. The correlations among the variables suggest that B.G affiliates are younger, larger, and more diversified than standalone 
companies. Descriptive Statistics, Correlation matrix, Multicollinearity test and Multiple Linear Regression Analysis has been presented.

\subsection{Descriptive Statistics}

Table A presents the descriptive statistics of 86 AFs and 90 NAFs for the years 2007-17. Our results are consistent with the studies of George et al. (2011). The performance of B.G AFs is better than the NAFs and B.G AFs are more profitable than the NAFs. This result confirms our first hypothesis that, higher cash flow increases the performance of AF's than NAF's. These findings are similar with the results of the study conducted by Ahmad et al. (2018).

The result of descriptive statistics implies that the investment sensitivity of B.G AFs is less than NAFs; as we measured the financing constraints through investment cash flow sensitivity. Thus, the average financial constraint of B.G AFs is 0.03 , which is less than that of NAFs (0.15). Hence, B.G AFs face less financial constraints than stand alone firms.

On average, the AFs companies are significantly higher leveraged (0.30) comparatively NAFs (0.26) that means the B.G AFs have more access to the capital markets. However, the AFs tend to have higher cash flows (0.07) than NAFs (0.05). Descriptive statistics indicate that on average, the AFs have higher growth opportunities (0.02) than NAFs have (0.01).

Table A shows that on average, the AFs size is 3.51 that is greater than the NAFs size (3.27). Hence, the firms large in size have more access to internal finance as compared to the small firms; so, B.G AFs have more access to the internal finances. Furthermore, the B.G AFs are almost three years older (38 years old) than NAFs (35 years old). The findings of Lensink et al. (2003) showed that the small firms are more financially constrained than the large firms.

\subsection{Correlation Matrix}

In Table B, the correlation results show that ROA is positively correlated with INV $(0.230)$, F.C (0.255), CF (0.325), GO (0.332) and FS (0.212) of the B.G AFs and NAF'S. It confirms our first hypothesis that states that higher Cash flow increases the performance of AF's than NAF's. In other words, the B.G AFs perform better than the NAFs. In both cases, ROA is positively correlated with INV, F.C, CF, GO, and FS. It means the investment opportunity, growth opportunity; cash flows, its size and its financial constraints also increase. B.G AFs are less financially constrained as compared to the non AFs. However, the investment and the growth opportunity of B.G AFs are higher than the NAFs. More the firm will be profitable, lower will be its reliance on the debt (leverage). For AFs, Firm's age (-0.016) has a negative impact on firm's profitability as well as on Firm's leverage. This finding is consistent with the results of the study conducted by Almeida et al. (2015). While for the NAFs, Firm's age has a positive impact on the firm's performance. These results are supported by the studies of Ahmad et al. (2018); Gedefaw Birhanu and Wezel (2020).

The correlation between the cash flows and investment is positive in the case of AFs and NAFs. However, this correlation is much lower for the B.G AFs (0.157) as compared to the correlation for the NAFs (0.181). This finding supports our second hypothesis, i.e. Lower Investment of AFs decreases the Cash Flows Sensitivity of AF's than NAFs. Less CF Sensitivity for the B.G AFs shows that the B.G AFs have better access to the internal funds as compared to the non AFs, as we have used cash flows as a proxy for internal funds. This finding is same with the results of the study conducted by the Lensink et al. (2003). For AFs, the investment is positively correlated with F.C (0.025), GO (0.231), FS (0.162) and FA (0.019). The investment is negatively correlated 
with the firm's leverage (-0.161). Same findings have been shown for the NAFs. It shows that better the investment of firm, higher its growth opportunity, its financing constraints and its size will be. Negative relationship between firm's leverage and the investment shows that, more the investment of a firm will be sensitive, lower will be its access to the capital markets. These results are consistent with the studies of He et al. (2013). The AFs financial constraints and the firm's size are less than NAFs. In other words, the B.G AFs are less financially constrained and are smaller in size than the NAFs. However, the growth opportunity of the B.G AFs is higher than the NAFs. These results are consistent with the study of Makina and Wale (2016).

\subsection{Multicollinearity}

The correlation coefficient between all variables is less than 0.5 , indicating that multicollinearity is not an issue that we need to address in the regression analysis. And our results are also supported by the study of Castaldi et al. (2019); Ellouze and Mnasri (2020); Yana (2020).

\subsection{Performance of AFs and Non AFs}

In the Table 3.2 Panel A, Multiple Linear Regression analysis has been performed to check the impact of Independent Variables on ROA and to test our first hypothesis that states, the Performance of B.G AFs is better than NAFs. We used Return on Assets to measure the firm's profitability. The reason why ROA is used as measuring firm profitability is that ROA avoids misrepresentations in measuring the performance because of firm's financing decisions and it captures the profitability of the firm as a whole.

The results illustrate that B.G AFs are more profitable while, the NAFs are less profitable. In the Table 3.2 Panel B, the coefficient of cash flows for the B.G AFs is 0.9511 and is significantly positive. But for the NAFs, CF Coefficient is 0.9323 . Higher the growth of a firm, more profitable it will be. So, B.G AFs have higher GO and are more profitable as compared to NAFs. According to the prior research, firm size is significantly negative in the case of B.G AFs indicating that the larger firms under perform. Identically, this is consistent result with the study of Sanan et al. (2019). Moreover, the B.G AFs are more profitable as compared to NAFs. Similar results are found in the studies of Ghose and Kabra (2017).

The results demonstrate that older firms are more profitable as compared to the younger firms. This result is consistent with the study of Mehmood and Farid Hasnu (2019). A negative value of the coefficient of interaction term (-0.5375) states that, the firms rely on external funds and firms are not financially constrained. Generally, this reflects the Trade off theory that states the negative relationship between interaction term (2 CFit x B.Git) of B.G AFs and firm performance means that firm is not financially constrained (Saeed and Athreye, 2014). Hence, all variables are significant at $5 \%$ significant level in the case of AFs. Likewise, for all variables of NAFs, the P-value is significant and less than 0.05 .

\subsection{Investment of AFs and NAFs}

Our second hypothesis states that Lower Investment of AFs decreases the Cash Flows Sensitivity of AF's than NAFs. Table 3.3 Panel A and Table 3.3 Panel B display the Multiple Linear Regression results estimated using the ordinary least squares estimation method (OLS). Similarly, in the Table 3.3 Panel A, the coefficient of constant for B.G AFs is -0.1144 that is a negative value. It exhibits that the sensitivity of investment is less for AFs. While, the coefficient of 
constant for the NAFs is 0.2053 that is a positive value that states the sensitivity of investment is more for NAFs. Additionally, the results propose that the NAFs are more financially constrained than AFs. Because, the B.G AFs enjoy the benefit of internal capital market as well as B.G AFs have good reputation.

In the Table 3.3 Panel B, the investment of NAFs is more sensitive. Indeed, our results are the reflection of Pecking order theory stating that, if the cash flow coefficient for a firm's investment is positive, then it means that the firm is financially constrained. Hence, our results demonstrate that the B.G AFs are not financially constrained (Saeed and Athreye, 2014). All things considered the findings suggest that the growth opportunity has a significant positive impact on the firm's investment because the investment has easy access to the internal funds (cash flows). These findings are similar to the results of Almeida et al. (2015).

Results state that the firm size has significant positive impact on the firm investment. The results of the study by Gupta and Mahakud (2018) supported our findings. Moreover, the firm's age has a significant negative impact on the AFs and Non-AFs investment. We can see that, the interaction term of B.G AFs has a significant positive impact on the firm investment. Additionally, all variables (Cash flows, interaction term, growth opportunity, firm size and firm age) reported a significant relationship with the investment of B.G AFs and NAFs. Furthermore, these findings are consistent with the studies of George et al. (2011); Saeed and Athreye (2014).

\subsection{Financing Constraints of AFs and NAFs}

The key difference between the AFs and NAFs is due to financing constraints. Nevertheless, the results supported our third hypothesis, i.e. Lower Financial constraints increase availability of funds for AF's than NAFs. Indeed, our findings are consistent with the studies of He et al. (2013).

In the Table 3.4 Panel A, Our Multiple Linear Regression analysis in the case of AFs, illustrates that the B.G AFs are less financially constrained as compared to the NAFs. Comparatively, these findings are similar to the results of Saeed and Athreye (2014). Accordingly, In the Table 3.4 panel B for the NAFs, the positive sign of CF coefficient value (0.0401) displays that the B.G AFs are more financially constrained (FC). It states that B.G AFs have higher GO than the NAFs. Indeed, the growth opportunity of B.G AFs is higher than the NAFs.

So, firm size has a significant negative impact on firms financing constraints. On the other hand, only firm age is insignificant in the case of B.G AFs while cash flows, interaction term, growth opportunity and FS are significant. We can see that only the growth opportunity is significant in the case of NAFs while other variables are insignificant.

\subsection{Leverage of AFs and NAFs}

Our fourth hypothesis states that the Higher Leverage increases access to the cheap source of financing for AFs than NAF's. In the Table 3.5, Panel A, the coefficient of c for B.G AFs (0.4016) is greater than the coefficient of $c$ for NAFs (0.3597). In other words, the B.G AFs are more leveraged than NAFs and have easy access to financial debt as well as they can avail the tax shield benefit as stated above in the trade off theory (Modigliani and Miller, 1958). Furthermore, the results demonstrate that if the B.G AFs are more leveraged then their GO will decrease by 0.0077 units because, too much reliance on the debt is not good for the firms. Hence, our finding are supported by the study of Ghosh (2010). FS has an inverse impact on the firm's leverage in the case of AFs and NAFs. Thus, these findings are supported by the results of Ghosh (2010). 
As shown above, Cash flows, interaction term, growth opportunity, firm size and firm age are insignificant in the case of B.G AFs while only cash flow of NAFs is insignificant. However, Growth opportunity, firm size and firm age are significant in the case of NAFs.

\section{Discussion}

Our findings demonstrate that the cash flows of B.G AFs have a negative impact on the firm investment indicating that the B.G AFs are not financially constrained. Similarly, the investment of B.G AFs would be less risky than NAF (Subramaniam, 2019). Simultaneously, the Japanese B.G firms exhibit a lower investmentcash flow sensitivity (George et al., 2011). In the meantime, the studies of Shin and Park (1999) found that non group firms in Japan and Korea exhibit a positive sensitivity of investments to the cash flows. Afterward, Kato et al. (2002) found a significantly lower sensitivity associated with the Japanese B.G AFs.

Generally, the results of NAFs display that there exists a positive relationship between NAFs and investment. It implies that the NAFs are financially constrained. B.G AFs enjoy the advantages of internal capital markets (Almeida et al., 2015; Carney et al., 2011). Moreover, the other firms in the group can lend B.G AFs and charge a rate less than that is charged by the external finances (Gopalan et al., 2007).

Basically, this research has been conducted to compare the performance of AFs and NAFs in Pakistan. As shown above, our findings confirmed that the B.G AFs are more profitable and have higher growth opportunities as compared to the NAFs. Furthermore, the B.Gs help the B.G AFs to overcome external market deficiencies by increasing their growth (Purkayastha, 2018). In addition, the B.Gs assist the B.G AFs to compete effectively and survive (Belenzon et al., 2013). Indeed, the B.Gs affiliation provide facilities to its member firms while facing the diverse changing in the institutional environment (Gubbi et al., 2015) and enables the member firms to efficiently react against the threats in the market. Hence in brief, there is a positive effect of B.G affiliation on the financial performance (Castaldi et al., 2019).

Fundamentally, the NAFs are more financially constrained than AFs. In fact, the B.G AFs are high leverage as compared to the NAFs (Mehmood and Farid Hasnu, 2019). Moreover, the member firms of a B.Gs have access to the intra-group loans and external capital markets (Ghatak and Kali, 2001). Subsequently, Majumdar and Sen (2007) found that the B.Gs tend to seek a relatively higher amounts of institutional borrowing.

\subsection{Conclusion}

In this paper, we compared the Performance, Investment, Financing Constraints and Leverage of AFs and NAFs in Pakistan. Our results supported our hypotheses. First, findings suggested that B.G AFs are more profitable than NAF'S. Second, AF's have higher growth opportunities as compared to the NAFs. Third, results show that NAFs are more financially constrained and have higher cash flows sensitivities than AF's. This suggests that AF's have easy access to the external findings. Moreover, it was established that the AF's leverage ratio is higher than the NAFs, demonstrated that the B.G AFs are more leveraged than NAFs and have easy access to financial debt. The study sheds new light on the profitability of AF's and NAF's, and presents a better perceptive of investment and fund raising in these firms. Our study proposes that growing firms and less financial constrained firms are better attraction for the foreign direct investment in Pakistan. By using the results of our study, Policy-makers can make strict policies 
to improve the financial conditions of NAF's in order to facilitate the NAF's access to financial markets.

\subsection{Policy Implications and Guidelines}

The findings of this study have important implications and guidelines for the readers, the policymakers, the management and the financial sector of Pakistan. Significantly, this study prospects the factors affecting the governance and the performance of business groups. By identifying the factors, practitioners can find guidelines for operating and controlling structures, resources and governance practices corresponding to their own positions as directors, managers, shareholders, investors or policymakers. Additionally, the B.G AFs have been found to have political implications and policy influence on their financing choice by removing the market distortions, keeping others on a disadvantage.

Previous studies could not check the relationship between the variables of B.G AFs vs. NAFs. Our study implications are important for future empirical research and help the researchers to relate financial constraint status with firms directly. Hence, our study implications can be useful for the corporate managers of B.G AFs as well as NAFs as they can make their policies and corporate investment decisions accordingly.

Investors can enjoy the benefits from this study and can take guidelines regarding fundraising and investment projects. Firms managers can get the guidelines from our study regarding cost of financial constraints and benefits of non-financially constrained firms. So, they can make corporate strategies according to it. Our research investigated that the B.G AFs attract the investors.

Thus, the findings of our study have implications for the corporate managers to plan appropriate investment policies so that the corporate investment and performance can be improved. With the help of findings of our study, the corporate managers of AFs and NAFs can find out the different possible factors influencing the performance of firms. Similarly, these findings will also help the management to understand and demand for the more effective corporate governance mechanisms to be implemented.

Policy distortion theory explains the ability of B.Gs to influence the policymakers. Consequently, Policymakers are recommended enhancing regulative structure and its implementation. Furthermore, Policymakers must consider the financially constrained firms and make policies to help such firms to reduce financial constraints and improve their access to external funds. The findings of our study have shown that the B.G AFs are less financially constrained as compared to the NAFs that imply the Pakistani government should provide a good governance and a healthy investment scenario in a country that attract the foreign investors. Indeed, the most of the NAFs are under the control of local government and their performance is poor in the terms of investment and cash flow sensitivity. In short, the Government can modify their investment plans in order to meet the cash flows on time.

\subsection{Limitations and Future Research}

As was previously stated, the research has been conducted to compare the performance, investment behavior, leverage, and cash flow sensitivity of AFs vs. NAFs in the Pakistan. Though, the results of previous studies strongly supported to the findings of our study. Our study is limited to the Pakistani Firms. As, the sample size of our study consists of 176 firms that is small. Future research can be conducted by taking large sample from the different countries. 
Conversely, the study can be conducted by taking the different sample period and different variables.

\section{References}

Aggarwal, R., Jindal, V., and Seth, R. (2019). Board diversity and firm performance: The role of business group affiliation. International Business Review, 28(6):101600.

Ahmad, I., Oláh, J., Popp, J., and Máté, D. (2018). Does business group affiliation matter for superior performance? evidence from pakistan. Sustainability, 10(9):3060.

Almeida, H., Kim, C.-S., and Kim, H. B. (2015). Internal capital markets in business groups: Evidence from the asian financial crisis. The Journal of Finance, 70(6):2539-2586.

Ayyagari, M. (NA). Asli demirgu c-kunt, and vojislav maksimovic (2008). How Important Are Financing Constraints, pages 483-516.

Belenzon, S., Berkovitz, T., and Rios, L. A. (2013). Capital markets and firm organization: How financial development shapes european corporate groups. Management Science, 59(6):1326-1343.

Bhaduri, S. N. (2005). Investment, financial constraints and financial liberalization: Some stylized facts from a developing economy, india. Journal of Asian economics, 16(4):704-718.

Buchuk, D., Larrain, B., Muñoz, F., and Urzúa, F. (2014). The internal capital markets of business groups: Evidence from intra-group loans. Journal of Financial Economics, 112(2):190-212.

Carney, M., Gedajlovic, E. R., Heugens, P. P., Van Essen, M., and Van Oosterhout, J. (2011). Business group affiliation, performance, context, and strategy: A meta-analysis. Academy of Management Journal, 54(3):437-460.

Castaldi, S., Gubbi, S. R., Kunst, V. E., and Beugelsdijk, S. (2019). Business group affiliation and foreign subsidiary performance. Global Strategy Journal, 9(4):595-617.

Chang, S. J. and Hong, J. (2000). Economic performance of group-affiliated companies in korea:
Intragroup resource sharing and internal business transactions. Academy of Management journal, 43(3):429-448.

Claessens, S., Fan, J. P., and Lang, L. H. (2006). The benefits and costs of group affiliation: Evidence from east asia. Emerging Markets Review, 7(1):126.

Cotei, C. and Farhat, J. B. (2009). The trade-off theory and the pecking order theory: are they mutually exclusive? Available at SSRN 1404576.

Donaldson, G. A., Linton, R. R., and Rodkey, G. V. (1961). A twenty-year survey of thromboembolism at the massachusetts general hospital, 1939-1959. New England Journal of Medicine, 265(5):208-214.

Ellouze, D. and Mnasri, K. (2020). Business group diversification, financial constraints and firm performance: the case of tunisian group affiliated firms. Journal of Management and Governance, 24(1):273-301.

Estrin, S., Poukliakova, S., and Shapiro, D. (2009). The performance effects of business groups in russia. Journal of Management Studies, 46(3):393420.

Gedefaw Birhanu, A. and Wezel, F. C. (2020). The competitive advantage of affiliation with business groups in the political environment: Evidence from the arab spring. Strategic Organization, page 1476127020952174 .

George, R., Kabir, R., and Qian, J. (2011). Investment-cash flow sensitivity and financing constraints: new evidence from indian business group firms. Journal of multinational financial management, 21(2):69-88.

Ghatak, M. and Kali, R. (2001). Financially interlinked business groups. Journal of Economics $\mathcal{E}$ Management Strategy, 10(4):591-619.

Ghose, B. and Kabra, K. C. (2017). Capital structure, group affiliation and financial constraints: Indian evidence. Prajnan, 46(1). 
Ghosh, S. (2010). Affiliation and firm performance: Evidence from indian business groups. The Manchester School, 78(3):183-200.

Gohar, R. (2013). Cross subsidization and its effect on pakistani business group's affiliated firm performance. Journal of Applied Finance and Banking, 3(3):207.

Gopalan, R., Nanda, V., and Seru, A. (2007). Affiliated firms and financial support: Evidence from indian business groups. Journal of Financial Economics, 86(3):759-795.

Gorodnichenko, Y., Schaefer, D., and Talavera, O. (2009). Financial constraints and continental business groups: Evidence from german konzerns. Research in International Business and Finance, 23(3):233-242.

Gubbi, S. R., Aulakh, P. S., and Ray, S. (2015). International search behavior of business group affiliated firms: Scope of institutional changes and intragroup heterogeneity. Organization Science, 26(5):1485-1501.

Gupta, G. and Mahakud, J. (2018). Business group affiliation and corporate investment: Evidence from indian companies. Journal of Management Research, 18(1):56-67.

He, J., Mao, X., Rui, O. M., and Zha, X. (2013). Business groups in china. Journal of Corporate Finance, 22:166-192.

Jindal, V. and Seth, R. (NA). How do firms finance investments in markets with business groups? evidence from acquisitions by indias listed firms.

Jung, B., Lee, D., Rhee, S. G., and Shin, I. (2019). Business group affiliation, internal labor markets, external capital markets, and labor investment efficiency. Asia-Pacific Journal of Financial Studies, 48(1):65-97.

Kato, H. K., Loewenstein, U., and Tsay, W. (2002). Dividend policy, cash flow, and investment in japan. Pacific-Basin Finance Journal, 10(4):443473.

Khanna, T. and Palepu, K. (2000). Is group affiliation profitable in emerging markets? an analysis of diversified indian business groups. The journal of finance, 55(2):867-891.
Kirch, G. and Kabbach-Castro, L. R. (2016). Do internal capital markets in business groups reduce financial constraints? Available at SSRN 2736265.

Kumar, S. and Ranjani, K. (2018). Financial constraints and investment decisions of listed indian manufacturing firms. Financial Innovation, $4(1): 1-17$.

Lamin, A. (2013). Business groups as information resource: An investigation of business group affiliation in the indian software services industry. Academy of Management Journal, 56(5):1487-1509.

Lensink, R., Van der Molen, R., and Gangopadhyay, S. (2003). Business groups, financing constraints and investment: The case of india. The Journal of Development Studies, 40(2):93-119.

Liebeskind, J. P. (2000). Internal capital markets: Benefits, costs, and organizational arrangements. Organization Science, 11(1):58-76.

Lin, C., Nguyen, H. C., and Tran, H. H. (2019). Comparative review of business group affiliates and firms performance: A meta-analysis research. Baltic Journal of Management.

Loderer, C. and Waelchli, U. (2010). Firm age and performance.

Majumdar, S. K. and Sen, K. (2007). The debt wish: Rent seeking by business groups and the structure of corporate borrowing in india. Public Choice, 130(1):209-223.

Makina, D. and Wale, L. E. (2016). The source of investment cash flow sensitivity in manufacturing firms: Is it asymmetric information or agency costs? South African Journal of Economic and Management Sciences, 19(3):388-399.

Malik, Q. U. Z. (2018). Capital structure dynamics and bank affiliation of business groups: Evidence from pakistan. SEISENSE Journal of Management, 1(1):22-37.

Mehmood, Y. and Farid Hasnu, S. A. (2019). Investment-cash flow sensitivity and financing constraints: Study of pakistani business group firms. Available at SSRN 3471042. 
Modigliani, F. and Miller, M. H. (1958). The cost of capital, corporation finance and the theory of investment. The American economic review, 48(3):261-297.

Moyen, N. (2004). Investment-cash flow sensitivities: Constrained versus unconstrained firms. The Journal of finance, 59(5):2061-2092.

Mukherjee, S. and Chanda, R. (2021). Financing constraints and exports: Evidence from manufacturing firms in india. Empirical Economics, 61(1):309-337.

Myers, S. C. and Majluf, N. S. (1984). Corporate financing and investment decisions when firms have information that investors do not have. Journal of financial economics, 13(2):187-221.

Poczter, S. (2018). Business groups in emerging markets: A survey and analysis. Emerging Markets Finance and Trade, 54(5):1150-1182.

Purkayastha, A. (2018). Performance of business group affiliated firms in emerging markets: Causal mediation analysis of internationalization and investment into innovation strategy. International Journal of Emerging Markets.

Saeed, A. and Athreye, S. (2014). Internal capital markets and outward foreign investment from india and china. In International Business and Institutions after the Financial Crisis, pages 93-108. Springer.
Sanan, N. K., Jaisinghani, D., and Yadav, S. (2019). Corporate governance, firm performance, and business group affiliation: evidence from india. Management Decision.

Shin, H.-H. and Park, Y. S. (1999). Financing constraints and internal capital markets: Evidence from koreanchaebols'. Journal of corporate finance, 5(2):169-191.

Subramaniam, B. (2019). Emerging market business groups and firm risk: Effects of internal capital markets, corporate governance and capital structure. $\mathrm{PhD}$ thesis, University of Sheffield.

VLACHVEI, A. and NOTTA, O. (2008). Foreignowned versus domestically-owned firms: evidence from greece. New Medit: Mediterranean Journal of Economics, Agriculture and Environment $=$ Revue Mediterraneenne dEconomie Agriculture et Environment, 7(4):13.

Yana, K. (2020). Internal capital markets in russian business groups: Evidence from corporate investments. , 14(2).

Yeh, Y.-H. and Lin, J. J. (2020). Investmentcash flow sensitivity to internal capital markets and shareholding structure: evidence from taiwanese business groups. Eurasian Business Review, pages 1-21. 


\section{Appendix}

Table A: Descriptive Statistics

\begin{tabular}{|c|c|c|c|c|c|c|c|c|c|c|c|}
\cline { 2 - 12 } \multicolumn{1}{c|}{} & Aff & $\begin{array}{c}\text { Non- } \\
\text { Aff }\end{array}$ & Aff & $\begin{array}{c}\text { Non- } \\
\text { Aff }\end{array}$ & Aff & $\begin{array}{c}\text { Non- } \\
\text { Aff }\end{array}$ & Aff & $\begin{array}{c}\text { Non- } \\
\text { Aff }\end{array}$ & Aff & $\begin{array}{c}\text { Non- } \\
\text { Aff }\end{array}$ \\
\cline { 2 - 12 } & \multicolumn{2}{|c|}{ Mean } & \multicolumn{2}{|c|}{ Median } & \multicolumn{2}{|c}{ Max } & \multicolumn{2}{c|}{ Min } & \multicolumn{2}{c|}{ SD } \\
\hline ROA & 0.04 & 0.01 & 0.03 & 0.02 & 0.69 & 0.86 & -0.97 & -2.75 & 0.12 & 0.21 \\
\hline INV & 1.11 & 1.21 & 1.06 & 1.09 & 4.18 & 3.02 & 0.39 & 0.05 & 0.23 & 0.32 \\
\hline F.C & 0.03 & 0.15 & 0.00 & 0.00 & 0.80 & 0.94 & -0.88 & -1.90 & 0.11 & 0.18 \\
\hline LEV & 0.39 & 0.26 & 0.37 & 0.24 & 3.27 & 2.56 & 0.00 & 0.00 & 0.22 & 0.34 \\
\hline CF & 0.07 & 0.05 & 0.06 & 0.06 & 0.73 & 0.86 & -3.33 & -2.68 & 0.17 & 0.21 \\
\hline GO & 0.02 & 0.01 & 0.04 & 0.03 & 1.42 & 1.10 & -1.72 & -2.83 & 0.20 & 0.28 \\
\hline FS & 3.51 & 3.27 & 3.50 & 3.32 & 5.07 & 4.77 & 1.46 & 0.06 & 0.58 & 0.66 \\
\hline FA & 38.73 & 35.06 & 36 & 29 & 104 & 157 & 13 & 3 & 15.59 & 19.47 \\
\hline
\end{tabular}

Notes:

a) Figures are for total 176 firms covering the period of 2007-2017

b) ROA consists of EBIT/Total Assets. INV is the Total Assets it / Total Assets it-1.

c) INV CF Sensitivity is the measure of Financing constraint and its proxy is CF it/ Investment it-1.

d) Leverage is measured by Total Debt/ Total Assets. CF is measured by (EBIT + depreciation) $\div$ TA.

e) Growth Opportunity is measured by the Natural Log of (Current Year Sales $\div$ Previous Year Sales).

f) Firm Size consists of $\log$ of total assets. Firm Age is the number of years since its incorporation date. 
Table B: Correlation Matrix

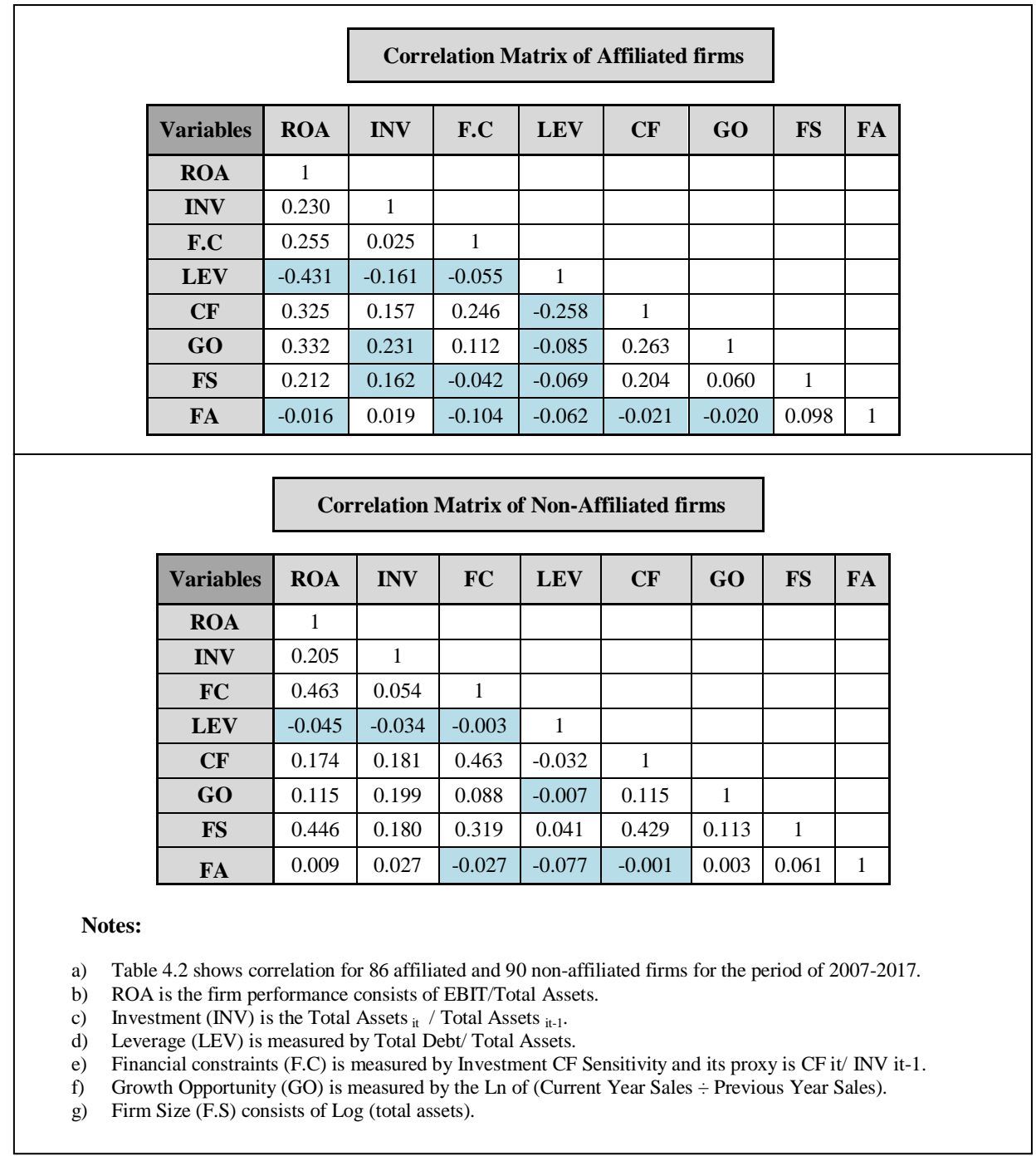

\begin{tabular}{|c|c|c|}
\hline $\begin{array}{c}\text { Sr. } \\
\#\end{array}$ & Variables & Abbreviation \\
\hline $\mathbf{1}$ & B.G AFs & B.G AF \\
\hline $\mathbf{2}$ & AFs & AF \\
\hline $\mathbf{3}$ & NON- AFs & NAF \\
\hline $\mathbf{4}$ & B.G AFs & GAF \\
\hline $\mathbf{5}$ & Business Group & B.G \\
\hline $\mathbf{6}$ & Cash Flows & CF \\
\hline
\end{tabular}

\begin{tabular}{|c|c|c|}
\hline $\begin{array}{c}\text { Sr. } \\
\#\end{array}$ & Variables & Abbreviation \\
\hline $\mathbf{7}$ & Growth Opportunity & GO \\
\hline $\mathbf{8}$ & Firm Size & FS \\
\hline $\mathbf{9}$ & Firm Age & FA \\
\hline $\mathbf{1 0}$ & Leverage & LEV \\
\hline $\mathbf{1 1}$ & Investment & INV \\
\hline $\mathbf{1 2}$ & Financing Constraints & FC \\
\hline $\mathbf{1 3}$ & Firm Performance & ROA \\
\hline
\end{tabular}


Table 3.1: Variables and Formulas

\begin{tabular}{|c|c|c|}
\hline Variables & Formulas & References \\
\hline Leverage (LEV) & Total Debt / Total Assets & $\begin{array}{l}\text { (Gupta \& Mahakud, 2018) } \\
\text { (Almeida et al., 2015) } \\
\text { (Buchuk et al., 2014) } \\
\text { (Ghosh, 2010) }\end{array}$ \\
\hline Investment (INV) & Total Assets it / Total Assets it-1 & (Gopalan et al., 2007) \\
\hline $\begin{array}{l}\text { Financing } \\
\text { Constraints }\end{array}$ & Investment CF Sensitivity = (CF it / Investment it-1) & (He et al., 2013) \\
\hline Firm Performance & (EBIT $\div$ Total Assets) & $\begin{array}{l}\text { (Ghose Biswajit \& Kailash Chandra Kabra, } \\
\text { 2017) }\end{array}$ \\
\hline Cash Flows & $(\mathrm{EBIT}+$ depreciation $) \div \mathrm{TA}$ & (Almeida et al., 2015). \\
\hline Growth Opportunity & Ln (Current Year Sales $\div$ Previous Year Sales) & (Ghosh, 2010) \\
\hline Firm Size & Log of Total Assets & $\begin{array}{l}\text { (George et al., 2011) } \\
\text { (Gupta \& Mahakud, 2018) } \\
\text { (Ghose Biswajit \& Kailash Chandra Kabra, } \\
\text { 2017) }\end{array}$ \\
\hline Firm Age & Current Year - Incorporation Year & $\begin{array}{l}\text { (George et al., 2011) } \\
\text { (Gupta \& Mahakud, 2018) } \\
\text { (Ghosh, 2010) }\end{array}$ \\
\hline B.G Firm & Dummy Variable & $\begin{array}{l}\text { (George et al., 2011) } \\
\text { (Gupta \& Mahakud, 2018) } \\
\text { (Majumdar \& Sen, 2006) }\end{array}$ \\
\hline Interaction Term & CF X Business Group & $\begin{array}{l}\text { (George et al., 2011) } \\
\text { (Gupta \& Mahakud, 2018) }\end{array}$ \\
\hline
\end{tabular}


Table 3.2 (Panel A): Performance of AFs

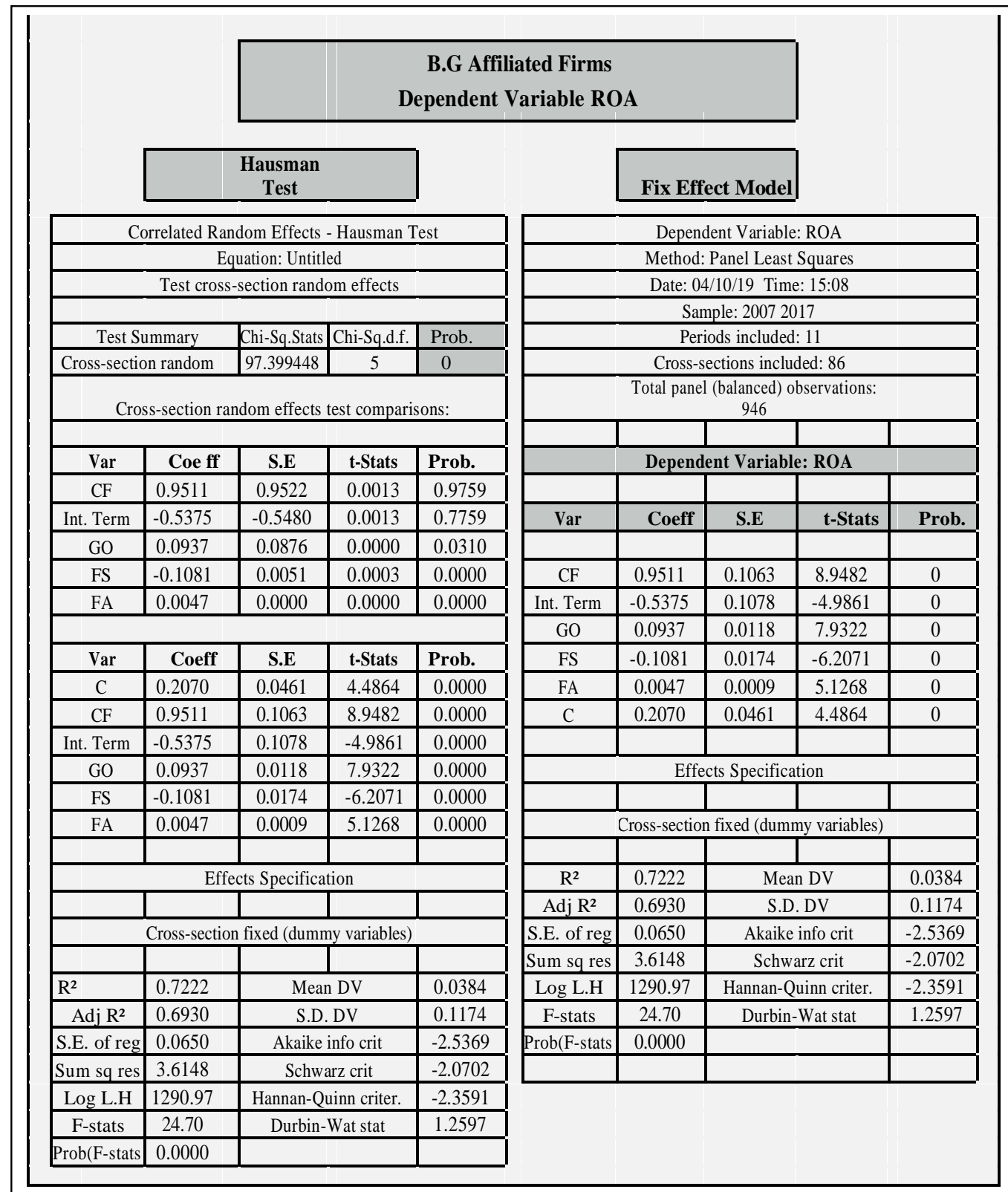

Notes: a) Figures of Regression Analysis are for 86 affiliated over the period of 2007-2017.

b) Firm performance (ROA) is dependent variable and comprises of EBIT/Total Assets.

c) Cash Flow (CF) is independent variable and is measured by (EBIT + depreciation) $\div$ TA.

d) Interaction Term (Int. Term) is independent variable and measured as CF x Dummy Variable.

e) Dummy variables is 1 if firm is affiliated to a business group, and 0 otherwise

f) Growth Opportunity (GO) is also independent variable that is measured by the Natural Log of (Current Year Sales $\div$ Previous Year Sales).

g) Firm Size (FS) is a control variable and consists of log of total assets.

h) Firm Age also control variable and calculated as the number of years since its incorporation. 
Table 3.2 (Panel B): Performance of NAFs

\section{Non- Affiliated Firms \\ Dependent Variable: ROA}

Hausman

Test

\begin{tabular}{|c|c|c|c|c|}
\hline \multicolumn{5}{|c|}{ Correlated Random Effects - Hausman Test } \\
\hline \multicolumn{5}{|c|}{ Equation: Untitled } \\
\hline \multicolumn{5}{|c|}{ Test cross-section random effects } \\
\hline \multicolumn{2}{|c|}{ Test Summary } & Chi-Sq.Stats & Chi-Sq.d.f. & Prob. \\
\hline \multicolumn{2}{|c|}{ Cross-sect rand } & 20.408471 & 4 & 0.0004 \\
\hline \multicolumn{5}{|c|}{ Cross-section random effects test comparisons: } \\
\hline & & & & \\
\hline Var & Coe ff & S.E & t-Stats & Prob. \\
\hline $\mathrm{CF}$ & 0.9323 & 0.9494 & 0.0000 & 0.0005 \\
\hline GO & 0.0062 & 0.0037 & 0.0000 & 0.0451 \\
\hline FS & 0.0211 & 0.0121 & 0.0000 & 0.1929 \\
\hline FA & -0.0011 & 0.0001 & 0.0000 & 0.0228 \\
\hline Var & Coeff & S.E & t-Stats & Prob. \\
\hline $\mathrm{C}$ & -0.0696 & 0.0231 & -3.0197 & 0.0026 \\
\hline $\mathrm{CF}$ & 0.9323 & 0.0097 & 96.3676 & 0.0000 \\
\hline GO & 0.0062 & 0.0053 & 1.1612 & 0.2459 \\
\hline $\mathrm{FS}$ & 0.0211 & 0.0076 & 2.7871 & 0.0054 \\
\hline FA & -0.0011 & 0.0005 & -2.0966 & 0.0363 \\
\hline \multicolumn{5}{|c|}{ Effects Specification } \\
\hline & & & & \\
\hline \multicolumn{5}{|c|}{ Cross-section fixed (dummy variables) } \\
\hline & & & & \\
\hline $\mathrm{R}^{2}$ & 0.9597 & \multicolumn{2}{|c|}{ Mean DV } & 0.0064 \\
\hline Adj $R^{2}$ & 0.9555 & \multicolumn{2}{|c|}{ S.D. DV } & 0.2111 \\
\hline S.E. of reg & 0.0446 & \multicolumn{2}{|c|}{ Akaike info crit } & -3.2942 \\
\hline Sum sq res & 1.7785 & \multicolumn{2}{|c|}{ Schwarz crit } & -2.8291 \\
\hline Log L.H & 1724.61 & \multicolumn{2}{|c|}{ Hannan-Quinn criter. } & -3.1173 \\
\hline F-stats & 229.22 & \multicolumn{2}{|c|}{ Durbin-Wat stat } & 1.7656 \\
\hline Prob(F-stats & 0 & & & \\
\hline
\end{tabular}

Fix Effect Model

\begin{tabular}{|c|c|c|c|c|}
\hline \multicolumn{5}{|c|}{ Dependent Variable: ROA } \\
\hline \multicolumn{5}{|c|}{ Method: Panel Least Squares } \\
\hline \multicolumn{5}{|c|}{ Date: $04 / 10 / 19$ Time: $16: 31$} \\
\hline \multicolumn{5}{|c|}{ Sample: 20072017} \\
\hline \multicolumn{5}{|c|}{ Periods included: 11} \\
\hline \multicolumn{5}{|c|}{ Cross-sections included: 90} \\
\hline \multicolumn{5}{|c|}{ Total panel (balanced) observations: 990} \\
\hline \multicolumn{5}{|c|}{ Cross-section SUR (PCSE) } \\
\hline & & & & \\
\hline \multicolumn{5}{|c|}{ Dependent Variable: ROA } \\
\hline & & & & \\
\hline Var & Coeff & S.E & t-Stats & Prob. \\
\hline $\mathbf{C F}$ & 0.9323 & 0.0116 & 80.1804 & 0.0000 \\
\hline GO & 0.0062 & 0.0036 & 1.7214 & 0.0855 \\
\hline FS & 0.0211 & 0.0080 & 2.6473 & 0.0083 \\
\hline FA & -0.0011 & 0.0005 & -2.1241 & 0.0339 \\
\hline $\mathrm{C}$ & -0.0696 & 0.0301 & -2.3130 & 0.0209 \\
\hline \multicolumn{5}{|c|}{ Effects Specification } \\
\hline & & & & \\
\hline \multicolumn{5}{|c|}{ Cross-section fixed (dummy variables) } \\
\hline & & & & \\
\hline $\mathrm{R}^{2}$ & 0.9597 & \multicolumn{2}{|c|}{ Mean DV } & 0.0064 \\
\hline Adj R ${ }^{2}$ & 0.9555 & \multicolumn{2}{|c|}{ S.D. DV } & 0.2111 \\
\hline S.E. of reg & 0.0446 & \multicolumn{2}{|c|}{ Akaike info crit } & -3.2942 \\
\hline Sum sq res & 1.7785 & \multicolumn{2}{|c|}{ Schwarz crit } & -2.8291 \\
\hline Log L.H & 1724.61 & \multicolumn{2}{|c|}{ Hannan-Quinn criter. } & -3.1173 \\
\hline F-stats & 229.22 & \multicolumn{2}{|c|}{ Durbin-Wat stat } & 1.7656 \\
\hline Prob(F-stats & 0.0000 & & & \\
\hline & & & & \\
\hline
\end{tabular}

Notes:

a) Figures of Regression Analysis are for 90 non-affiliated firms over the period of 2007-2017.

b) Firm performance (ROA) is dependent variable and comprises of EBIT/Total Assets.

c) Cash Flow (CF) is independent variable and is measured by (EBIT + depreciation) $\div$ TA.

d) Interaction Term (Int. Term) is independent variable and measured as CF x Dummy Variable.

e) Dummy variables is 1 if firm is affiliated to a business group, and 0 otherwise

f) Growth Opportunity (GO) is also independent variable that is measured by the Natural Log of (Current Year Sales $\div$ Previous Year Sales).

g) Firm Size (FS) is a control variable and consists of log of total assets.

h) Firm Age also control variable and calculated as the number of years since its incorporation. 
Table 3.3 (Panel A): Investment of AFs

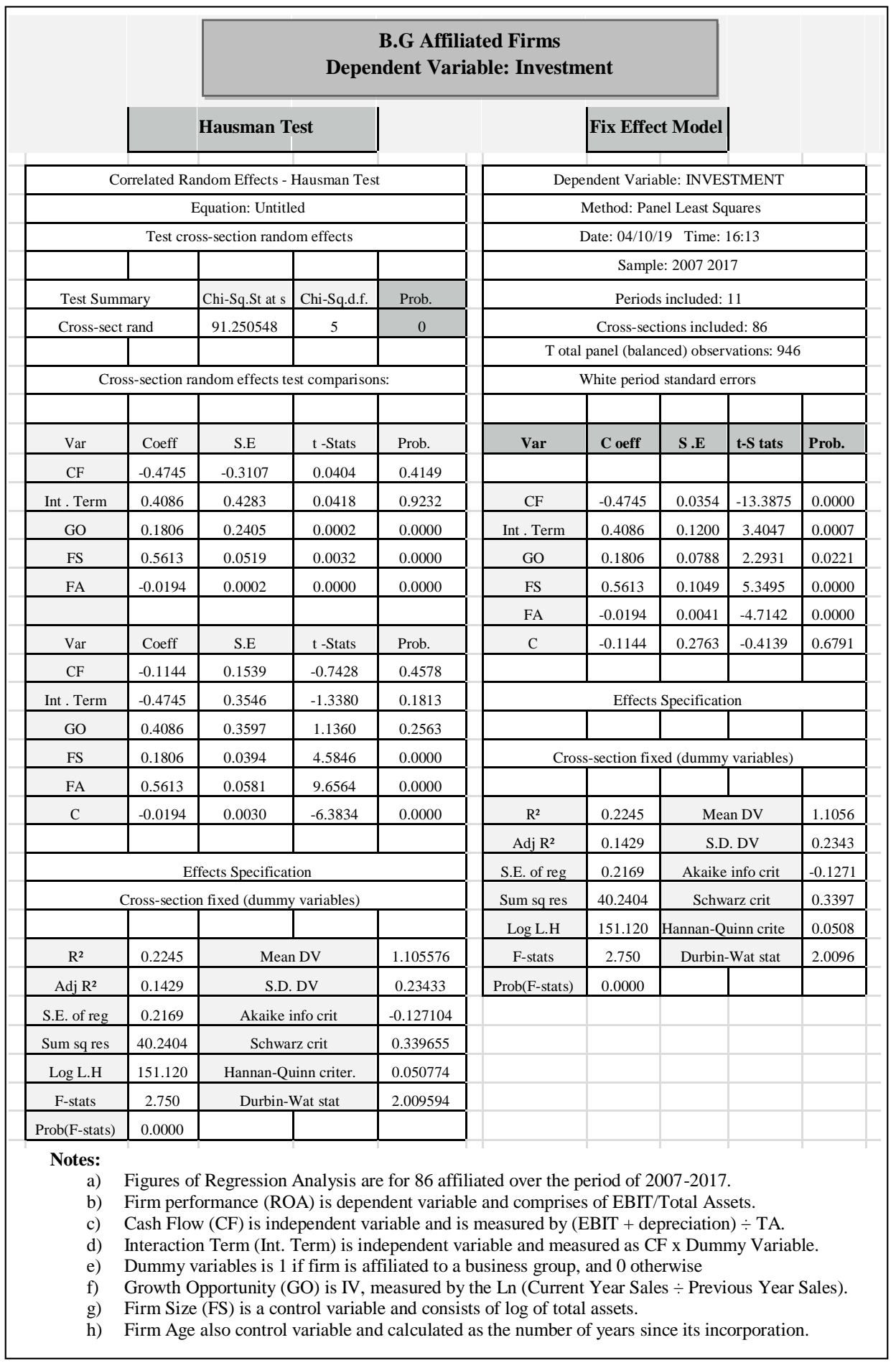


Table 3.3 (Panel B): Investment of NAFs

\begin{tabular}{|c|c|c|c|c|c|c|c|c|c|}
\hline & & \multicolumn{6}{|c|}{$\begin{array}{l}\text { Non -Affiliated Firms } \\
\text { Dependent Variable: Investment }\end{array}$} & & \\
\hline & \multicolumn{3}{|c|}{ Hausman Test } & & & \multicolumn{2}{|c|}{ Fix Effect Model } & & \\
\hline \multicolumn{5}{|c|}{ Correlated Random Effects - Hausman Test } & \multicolumn{5}{|c|}{ Dependent Variable: INVESTMENT } \\
\hline \multicolumn{5}{|c|}{ Equation: Untitled } & \multicolumn{5}{|c|}{ Method: Panel Least Squares } \\
\hline \multicolumn{5}{|c|}{ Test cross-section random effects } & \multicolumn{5}{|c|}{ Date: $04 / 10 / 19$ Time: $16: 47$} \\
\hline & & & & & \multicolumn{5}{|c|}{ Sample: 20072017} \\
\hline \multicolumn{2}{|c|}{ Test Summary } & Chi-Sq.Stats & Chi-Sq.d.f. & Prob. & \multicolumn{5}{|c|}{ Periods included: 11} \\
\hline \multicolumn{2}{|c|}{ Cross-sect rand } & 73.198069 & 4 & 0 & \multicolumn{5}{|c|}{ Cross-sections included: 90} \\
\hline & & & & & \multicolumn{5}{|c|}{ Total panel (balanced) observations: 990} \\
\hline \multicolumn{10}{|c|}{ Cross-section random effects test comparisons: } \\
\hline & & & & & & & & & \\
\hline Var & Coeff & S.E & t-Stats & Prob. & Var & Coe ff & S.E & t-Stats & Prob. \\
\hline $\mathrm{CF}$ & 0.1902 & 0.1710 & 0.0016 & 0.6286 & & & & & \\
\hline GO & 0.1503 & 0.1912 & 0.0001 & 0.0001 & $\mathrm{CF}$ & 0.1902 & 0.0639 & 2.9740 & 0.0030 \\
\hline FS & 0.4216 & 0.0564 & 0.0022 & 0.0000 & GO & 0.1503 & 0.0352 & 4.2730 & 0.0000 \\
\hline \multirow[t]{3}{*}{ FA } & -0.0140 & 0.0003 & 0.0000 & 0.0000 & $\mathrm{FS}$ & 0.4216 & 0.0500 & 8.4343 & 0.0000 \\
\hline & & & & & FA & -0.0140 & 0.0033 & -4.1931 & 0.0000 \\
\hline & & & & & $\mathrm{C}$ & 0.2053 & 0.1524 & 1.3467 & 0.1784 \\
\hline Var & Coeff & S.E & t-Stats & Prob. & & & & & \\
\hline $\mathrm{CF}$ & 0.2053 & 0.1524 & 1.3467 & 0.1784 & & & & & \\
\hline $\mathrm{GO}$ & 0.1902 & 0.0639 & 2.9740 & 0.0030 & \multicolumn{5}{|c|}{ Effects Specification } \\
\hline $\mathrm{FS}$ & 0.1503 & 0.0352 & 4.2730 & 0.0000 & & & & & \\
\hline FA & 0.4216 & 0.0500 & 8.4343 & 0.0000 & \multicolumn{5}{|c|}{ Cross-section fixed (dummy variables) } \\
\hline \multirow[t]{3}{*}{$\mathrm{C}$} & -0.0140 & 0.0033 & -4.1931 & 0.0000 & & & & & \\
\hline & & & & & $\mathrm{R}^{2}$ & 0.2232 & \multicolumn{2}{|c|}{ Mean DV } & 1.105 \\
\hline & & & & & Adj $R^{2}$ & 0.1426 & \multicolumn{2}{|c|}{ S.D. DV } & 0.318 \\
\hline \multicolumn{5}{|c|}{ Effects Specification } & S.E. of reg & 0.2945 & \multicolumn{2}{|c|}{ Akaike info crit } & 0.483 \\
\hline \multicolumn{5}{|c|}{ Cross-section fixed (dummy variables) } & Sum sq res & 77.70 & \multicolumn{2}{|c|}{ Schwarz crit } & 0.948 \\
\hline & & & & & Log L.H & -145.04 & Hannan- & inn criter & 0.660 \\
\hline $\mathrm{R}^{2}$ & 0.2232 & Mea & DV & 1.1053 & F-stats & 2.77 & Durb & Wat stat & 2.174 \\
\hline Adj R $^{2}$ & 0.1426 & S.D & $\mathrm{DV}$ & 0.3180 & Prob(F-stats) & 0.0000 & & & \\
\hline S.E. of reg & 0.2945 & Akaike & nfo crit & 0.4829 & & & & & \\
\hline Sum sq res & 77.6988 & Schw & rz crit & 0.9479 & & & & & \\
\hline Log L.H & -145.04 & Hannan-Q & inn criter. & 0.6597 & & & & & \\
\hline F-stats & 2.77 & Durbin & Nat stat & 2.1737 & & & & & \\
\hline Prob(F-stats) & 0.0000 & & & & & & & & \\
\hline
\end{tabular}

Notes:

a) Figures of Regression Analysis are for 86 affiliated over the period of 2007-2017.

b) Firm performance (ROA) is dependent variable and comprises of EBIT/Total Assets.

c) Cash Flow $(\mathrm{CF})$ is independent variable and is measured by (EBIT + depreciation) $\div$ TA.

d) Interaction Term (Int. Term) is independent variable and measured as CF x Dummy Variable.

e) Dummy variables is 1 if firm is affiliated to a business group, and 0 otherwise

f) Growth Opportunity (GO) is IV, measured by the Ln (Current Year Sales $\div$ Previous Year Sales).

g) Firm Size (FS) is a control variable and consists of log of total assets.

h) Firm Age also control variable and calculated as the number of years since its incorporation. 
Table 3.4 (Panel A): Financing Constraints and AFs

\begin{tabular}{|c|c|c|c|c|c|c|c|c|c|}
\hline & & \multicolumn{5}{|c|}{$\begin{array}{l}\text { B.G Affiliated Firms } \\
\text { Dependent Variable: Financing Constraints }\end{array}$} & & & \\
\hline & & $\begin{array}{l}\text { Hausman } \\
\text { Test }\end{array}$ & & & & $\begin{array}{l}\text { Fix Eff } \\
\text { Model }\end{array}$ & & & \\
\hline \multicolumn{5}{|c|}{ Correlated Random Effects - Hausman Test } & \multicolumn{5}{|c|}{$\begin{array}{c}\text { Dependent Variable: Financing } \\
\text { Constraints }\end{array}$} \\
\hline \multicolumn{5}{|c|}{$\begin{array}{c}\text { Equation: } \\
\text { Untitled } \\
\end{array}$} & \multicolumn{5}{|c|}{$\begin{array}{c}\begin{array}{c}\text { Method: Panel Least } \\
\text { Squares }\end{array} \\
\end{array}$} \\
\hline \multicolumn{5}{|c|}{ Test cross-section random effects } & \multicolumn{5}{|c|}{$\begin{array}{c}\text { Date: 04/10/19 Time: } \\
15: 11 \\
\end{array}$} \\
\hline & & & & & \multicolumn{5}{|c|}{ Sample: 20072017} \\
\hline \multicolumn{2}{|c|}{ Test Summary } & Chi-Sq.Stats & Chi-Sq.d.f. & Prob. & \multicolumn{5}{|c|}{ Periods included: 11} \\
\hline \multicolumn{2}{|c|}{ Cross-sect rand } & 23.977989 & 5 & 0.00 & \multicolumn{5}{|c|}{ Cross-sections included: 86} \\
\hline & & & & & Total p & nel (balanc & ed) obser & ations: 946 & \\
\hline \multicolumn{5}{|c|}{ Cross-section random effects test comparisons: } & \multicolumn{5}{|c|}{ White period standard errors } \\
\hline & & & & & & & & & \\
\hline Var & Coeff & S.E & $\mathrm{t}$-Stats & Prob. & Var & Coeff & S.E & t-S tats & Prob. \\
\hline $\mathrm{CF}$ & -0.0326 & 0.0452 & 0.0026 & 0.1310 & & & & & \\
\hline Int. Term & 0.1192 & 0.0615 & 0.0028 & 0.2718 & $\mathrm{CF}$ & -0.0326 & 0.0172 & -1.8932 & 0.0587 \\
\hline $\mathrm{GO}$ & 0.0329 & 0.0313 & 0.0000 & 0.6894 & Int. Term & 0.1192 & 0.0286 & 4.1722 & 0.0000 \\
\hline FS & -0.0513 & -0.0198 & 0.0006 & 0.1786 & $\mathrm{GO}$ & 0.0329 & 0.0140 & 2.3467 & 0.0192 \\
\hline \multirow[t]{2}{*}{$\mathrm{FA}$} & 0.0001 & -0.0007 & 0.0000 & 0.5516 & FS & -0.0513 & 0.0260 & -1.9764 & 0.0484 \\
\hline & & & & & FA & 0.0001 & 0.0013 & 0.0694 & 0.9447 \\
\hline Var & Coeff & S.E & $\mathrm{t}$-Stats & Prob. & $\mathrm{C}$ & 0.1982 & 0.0914 & 2.1684 & 0.0304 \\
\hline $\mathrm{CF}$ & 0.1982 & 0.0674 & 2.9419 & 0.0034 & & & & & \\
\hline Int. Term & -0.0326 & 0.1552 & -0.2100 & 0.8337 & \multicolumn{5}{|c|}{ Effects Specification } \\
\hline $\mathrm{GO}$ & 0.1192 & 0.1574 & 0.7576 & 0.4489 & & & & & \\
\hline FS & 0.0329 & 0.0172 & 1.9072 & 0.0568 & \multicolumn{5}{|c|}{ Cross-section fixed (dummy variables) } \\
\hline FA & -0.0513 & 0.0254 & -2.0189 & 0.0438 & & & & & \\
\hline \multirow[t]{2}{*}{$\mathrm{C}$} & 0.0001 & 0.0013 & 0.0659 & 0.9475 & $\mathrm{R}^{2}$ & 0.3645 & \multicolumn{2}{|c|}{ Mean DV } & 0.0276 \\
\hline & & & & & $\operatorname{Adj~R}^{2}$ & 0.2976 & \multicolumn{2}{|c|}{ S.D. DV } & 0.1133 \\
\hline \multicolumn{5}{|c|}{ Effects Specification } & S.E. of reg & 0.0949 & Akaike & info crit & -1.7803 \\
\hline \multicolumn{5}{|c|}{$\begin{array}{c}\text { Cross-section fixed (dummy } \\
\text { variables) }\end{array}$} & Sum sq res & 7.7039 & Schn & arz crit & -1.3135 \\
\hline & & & & & Log L.H & 933.06 & $\begin{array}{l}\text { Hannan } \\
\text { criter }\end{array}$ & Quinn & -1.6024 \\
\hline $\mathrm{R}^{2}$ & 0.3645 & Mear & & 0.0276 & F-stats & 5.4480 & Durbin & Wat stat & 1.6255 \\
\hline Adj R ${ }^{2}$ & 0.2976 & S.D. & & 0.1133 & Prob(F-stats) & 0.0000 & & & \\
\hline S.E. of reg & 0.0949 & Akaike & fo crit & -1.7803 & & & & & \\
\hline Sum sq res & 7.7039 & Schwa & $\mathrm{z}$ crit & -1.3135 & & & & & \\
\hline Log L.H & 933.06 & Hannan-Q & inn criter. & -1.6024 & & & & & \\
\hline F-stats & 5.4480 & Durbin-I & at stat & 1.6255 & & & & & \\
\hline Prob(F-stats) & 0.0000 & & & & & & & & \\
\hline Notes: & & & & & & & & & \\
\hline a) & Figures of & Regression A & talysis are $\mathrm{f}$ & or 86 affil & ed over the p & riod of 2 & $07-2017$ & & \\
\hline b) & Firm perf & mance (ROA & is depende & nt variabl & nd comprises & of EBIT/ & Total As & ets. & \\
\hline c) & Cash Flov & $(\mathrm{CF})$ is indep & endent varia & ble and is & easured by $(\mathrm{E}$ & $\mathrm{BIT}+\mathrm{de}$ & reciatio & 1) $\div$ TA. & \\
\hline d) & Interactio & Term (Int. T & $\mathrm{rm}$ ) is inder & endent va & ble and meas & Ired as $\mathrm{C}$ & x Dum & ny Varial & \\
\hline e) & Dummy v & riables is 1 if & firm is affil & ated to a & iness group, & nd 0 othe & rwise & & \\
\hline f) & Growth O & portunity $(\mathrm{G}$ & ) is IV, me & sured by & Ln (Current & Year Sale & $s \div$ Prev & ous Year & Sales). \\
\hline g) & Firm Size & $\mathrm{FS}$ ) is a cont & ol variable & nd consis & of $\log$ of total & assets. & & & \\
\hline h) & Firm Age & lso control ve & riable and c & alculated & the number o & years sin & ce its in & orporatio & \\
\hline
\end{tabular}




\section{Table 3.4 (Panel B): Financing Constraints and NAFs}

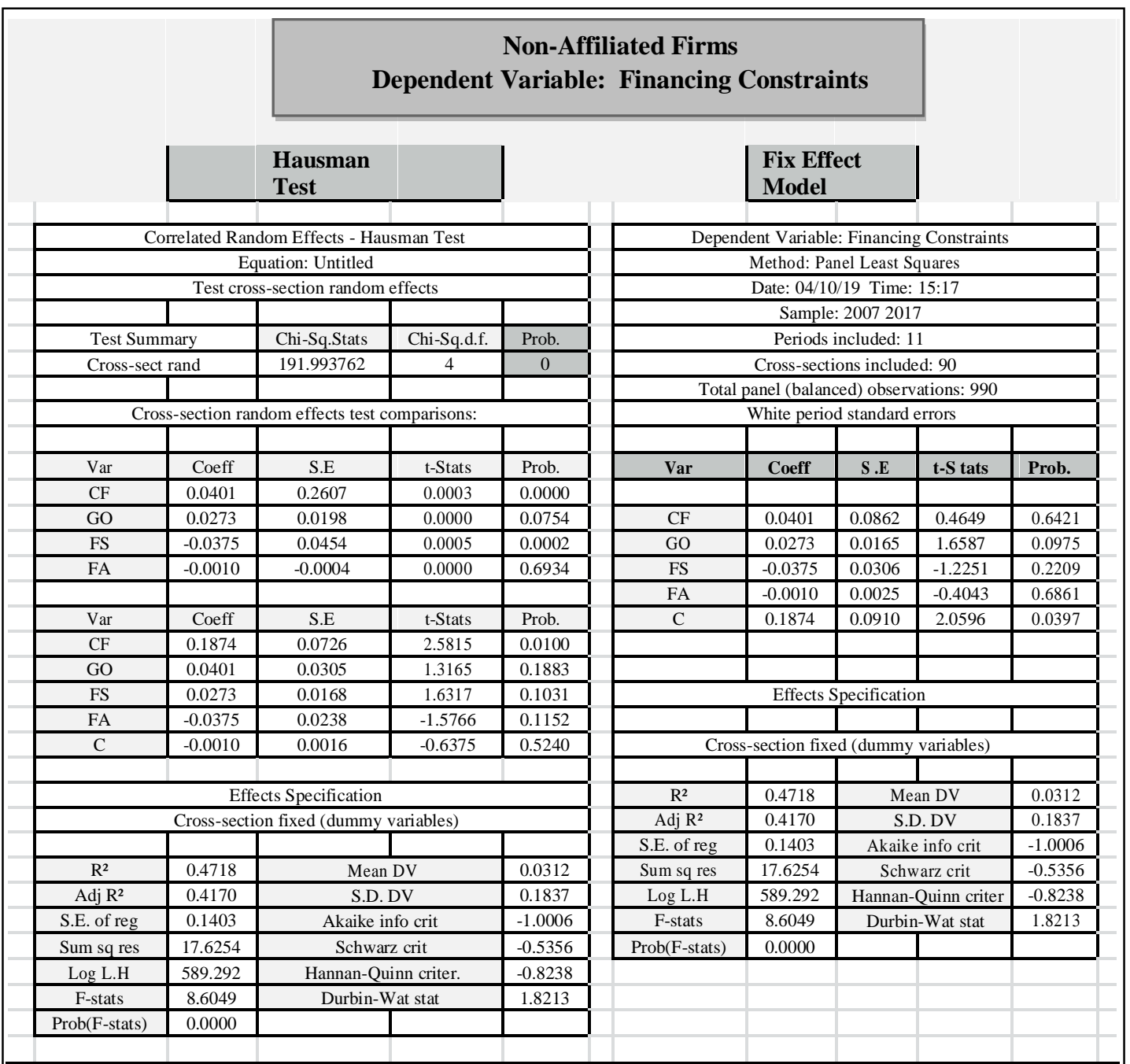

Notes:

a) Figures of Regression Analysis are for 86 affiliated over the period of 2007-2017.

b) Firm performance (ROA) is dependent variable and comprises of EBIT/Total Assets.

c) Cash Flow (CF) is independent variable and is measured by (EBIT + depreciation) $\div$ TA.

d) Interaction Term (Int. Term) is independent variable and measured as CF x Dummy Variable.

e) Dummy variables is 1 if firm is affiliated to a business group, and 0 otherwise

f) Growth Opportunity (GO) is IV, measured by the Ln (Current Year Sales $\div$ Previous Year Sales).

g) Firm Size (FS) is a control variable and consists of log of total assets.

h) Firm Age also control variable and calculated as the number of years since its incorporation 
Table 3.5 (Panel A): Leverage and AFs

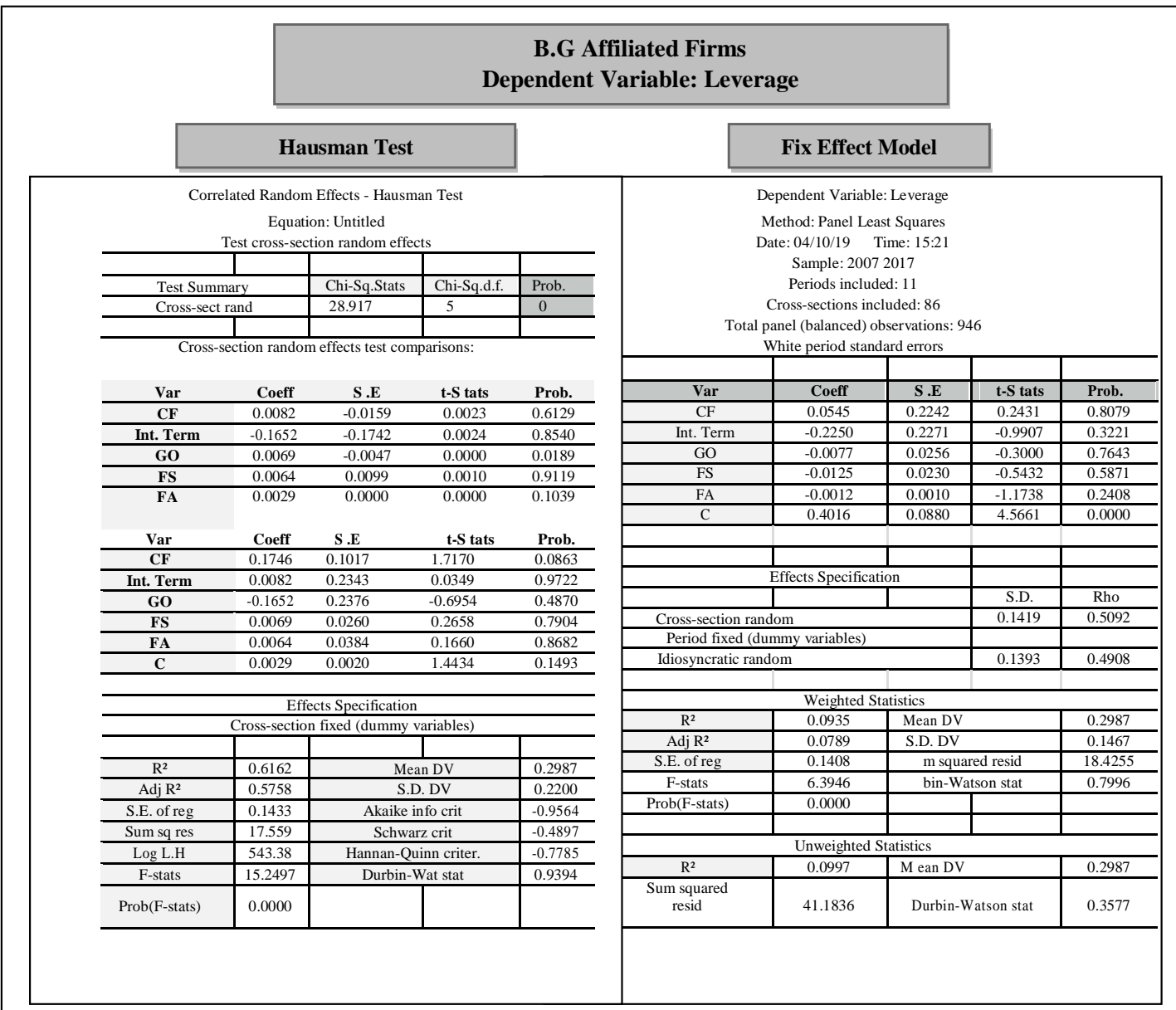

Notes:

a) Figures of Regression Analysis are for 86 affiliated over the period of 2007-2017.

b) Firm performance (ROA) is dependent variable and comprises of EBIT/Total Assets.

c) Cash Flow $(\mathrm{CF})$ is independent variable and is measured by (EBIT + depreciation $) \div$ TA.

d) Interaction Term (Int. Term) is independent variable and measured as CF x Dummy Variable.

e) Dummy variables is 1 if firm is affiliated to a business group, and 0 otherwise

f) Growth Opportunity (GO) is IV, measured by the Ln (Current Year Sales $\div$ Previous Year Sales).

g) Firm Size (FS) is a control variable and consists of log of total assets.

h) Firm Age also control variable and calculated as the number of years since its incorporation. 
Table 3.5 (Panel B): Leverage of NAFs

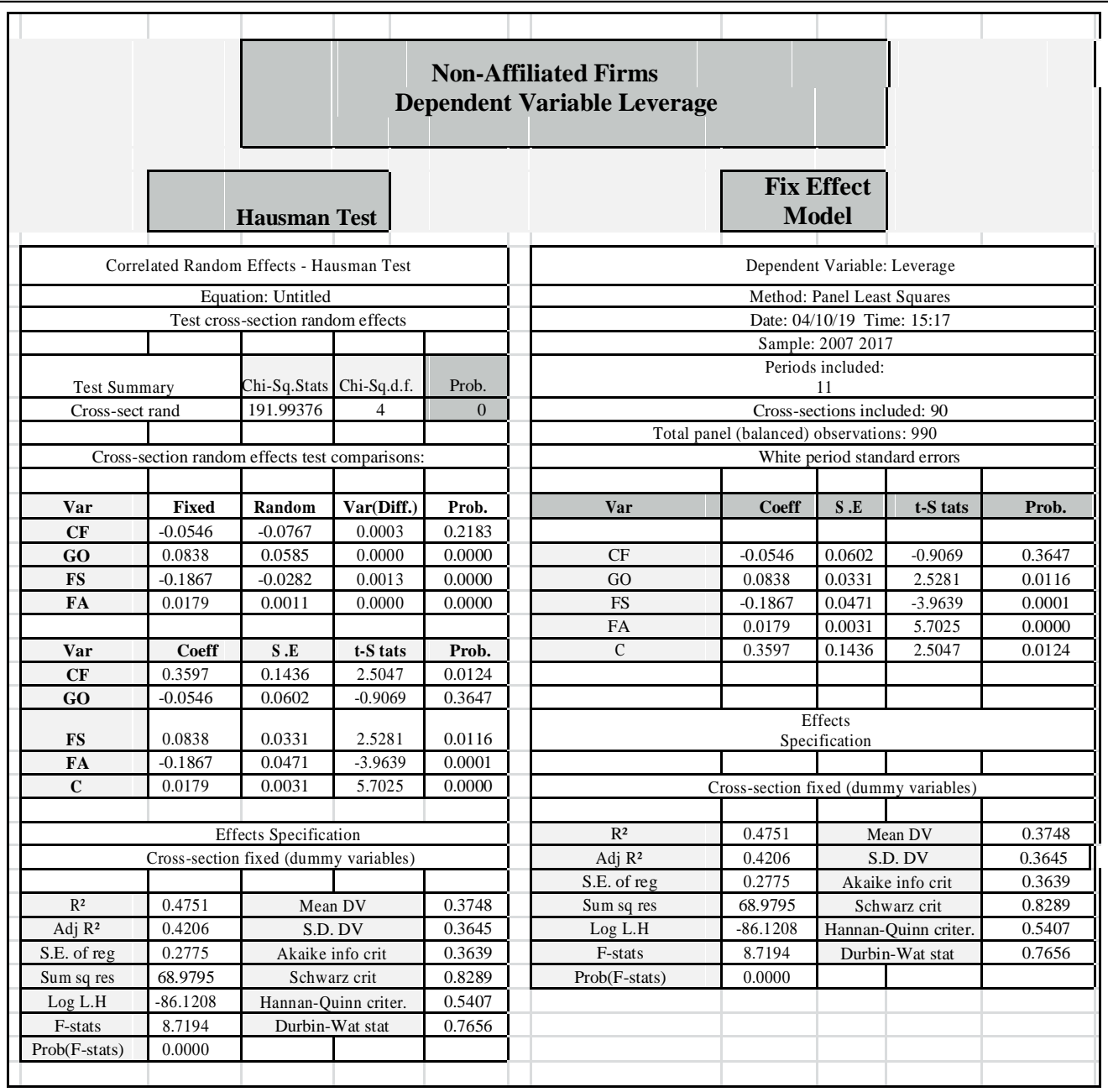

Notes:

a) Figures of Regression Analysis are for 86 affiliated over the period of 2007-2017.

b) Firm performance (ROA) is dependent variable and comprises of EBIT/Total Assets.

c) Cash Flow (CF) is independent variable and is measured by (EBIT + depreciation) $\div$ TA.

d) Interaction Term (Int. Term) is independent variable and measured as CF x Dummy Variable.

e) Dummy variables is 1 if firm is affiliated to a business group, and 0 otherwise

f) Growth Opportunity (GO) is IV, measured by the Ln (Current Year Sales $\div$ Previous Year Sales).

g) Firm Size (FS) is a control variable and consists of log of total assets.

h) Firm Age also control variable and calculated as the number of years since its incorporation. 